\title{
Impact of Employee Engagement on Turnover Intention: Study of Third Space Global (Pvt) Limited
}

\author{
F. Z. Naufer ${ }^{1}$ and P. D. A. S. Kumar ${ }^{2}$ \\ ${ }^{1}$ PQHRM Student, Charted Institute of Personnel Management, Sri Lanka \\ ${ }^{2}$ Doctoral Student, University of Kelaniya, Sri Lanka \\ 1Zayn19n@gmail.com, ${ }^{2}$ sanathpalliyaguru@gmail.com
}

\begin{abstract}
This study was carried out with the purpose of examining the importance of employee engagement to retain staff in a service providing industry and examining the relationship between the various factors that affect employee engagement as well as the intention to turnover. This study was carried out based on the non-executive level staff at Third Space global PVT Ltd. The sample size is one hundred non -executive level employees out of the population of two hundred and fifty. In determining the sample size, the table introduced by Sekaran (2006) was used. The questionnaire was developed by the researcher using different standard questionnaires depending on each variable and the questions were designed with Likert scale ranking strongly agree to strongly disagree. Findings revealed that the rate of attrition was quite high within the nonexecutive staff in the company. Further the research recommends to research on a new set of factors that aid in building employee engagement towards the company. Finally, the researcher presents his recommendations to renew the existing engagement techniques implied by the company, and the organization should focus on the salary based on the years of experience as well as their educational level.
\end{abstract}

Keywords: Employee engagement, Turnover intention, Non-executive level employees

\section{Introduction}

Today, society and business are witnessing an unprecedented change in terms of the global nature of work and the diversity of the workforce. Organizations in the world are moving forward into a boundary-less environment. Having the right talent in pivotal roles at the right time is of strategic importance, making a difference to revenues, innovation, and organization effectiveness (Ashton and Morton, 2005). In the current global market, where competitiveness is at its highest peak, it is identified that human resources are the major assets that contribute to the success of an organization.

Third Space Global, a British owned company providing tutoring services to primary students in the UK established in 2016 has employees over 200 only within the island. The company specializes in teaching Mathematics where one to one tuition is the brand that the company is well known for. There are many other companies across the globe in a similar industry providing tutoring services all over the world with different subjects. Some of them teach the same subjects where many of them occupy many other subjects as well, but Third Space 
Global takes the pride of the only online tutoring service provider who is specialized in Mathematics. The company utilizes software which is an infusion of both Skype and a classroom which is user friendly and interactive to both tutors and students. The current population of employees are mostly at the age between school leavers to mid$20 \mathrm{~s}$ to $35 \mathrm{~s}$, and there are over 250 employees working only within Colombo under the tutor grade. Third Space Global is an innovation-based academic organization where they strive in providing the best quality of education to its customers while improvising the creativity within the employees and developing them professionally. Their values are based on 5 pillars - Caring, Commitment, Integrity, Innovation and Excellence which focuses and revolves around its employees.

This research focuses on factors that affect employee turnover in Third Space Global and the influence of employee engagement and satisfaction in employee turnover rate in the company. This study is based only on the tutor grade employees where the company has more than 50 employees in executive and managerial positions as well.

\section{Problem Statement}

Turnover has been a critical aspect of a company where it contributes to the productivity and profitability of the organization at large percentages. The level of employee engagement and satisfaction vary from time to time which reflects the commitment of an employee and their intention to remain within the company. This study is focused on identifying these key factors with regards to the service providing company Third Space Global. As a part of the preliminary investigations which were carried out it was observed that many tutors leave the company within the first 6 months from their onboarding. This was further investigated by contacting the Human Resource Manager and according to the data collected from the HR dashboard and reports it was identified that there was a considerable rate of attrition at different periods of the year.

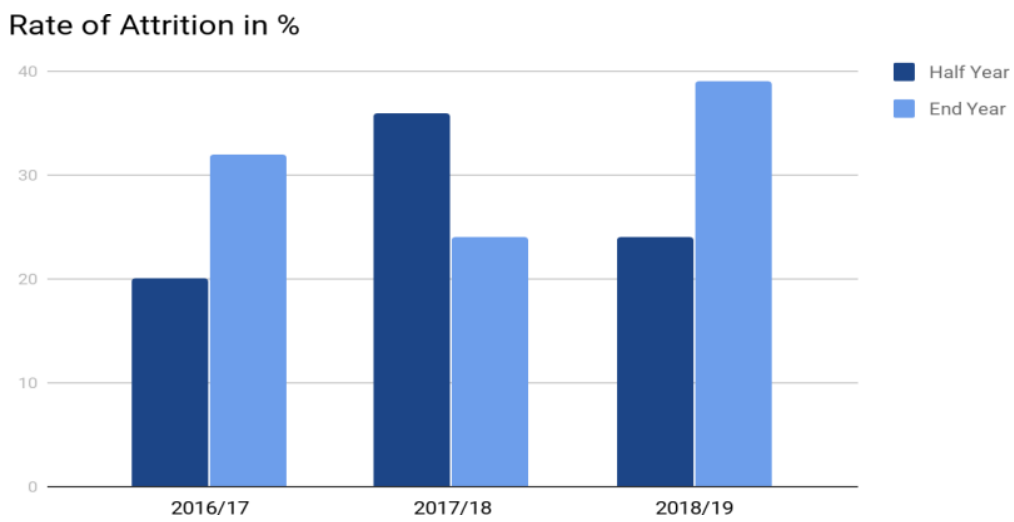

Figure 01: Data Analysis of Preliminary Survey

Source: Authors, 2019 
Third Space Global, being well known for one to one tuition service provider, loses its employer brand by not being able to provide 1 tutor for 1 student within the given period of the term. This is mainly due to high absenteeism and turnover. Moreover, this has resulted in less productivity and low quality of services being delivered. Replacement of these skilled tutors' costs both time and money in terms of recruitment and training. Skill depreciation is also another factor that affects due to excessive turnover, people who remain in the organization may see the current state as a burden on them and also employees with lacking skills will be pressured due to high demand in the industry.

\section{Objectives of the Study}

This study focuses on key objectives as follows.

\section{General Objective:}

To identify the factors affecting employee turnover and to assess the relationship between employee engagement, and intention to turnover.

\section{Specific Objectives:}

i. Identify key factors affecting intention to turnover within the tutor grade employee in the company.

ii. Explore the level of employee engagement existing in the company.

iii. Analyze the relationship between employee engagement and turnover intention.

iv. Study the impact of strategies of techniques that influence the rate of attrition.

\section{Literature Review}

\section{Labor Turnover}

Labor turnover can be expressed as a rate at which employees leave a business enterprise (Hedwiga, 2011). Several other terms have been used interchangeably with employee turnover, such terms include quits, attrition, exits, mobility, migration, or succession (Morrell, John \& Adrian, 2004). It represents the relative rate at which a business enterprise gains or losses its employees (Marisoosay, 2009). Kazi and Zedah (2011) describe employees' turnover as the regular change of employees around the employment market among organizations, professions, and career; and between the conditions of full employment and that of being without a job.

As per the above definitions, it is identified that labor turnover depicts a measure of employment within a given period in an organization and the frequency of replacement in an organization with regards to its employees. Previous studies have reported that employee turnover could pose a serious threat to the growth and productivity of any business organization (Tettey, 2006; Ally, 2011; Mrope \& Bangi, 2014). In fact, Armstrong (2004) recognizes that employees' turnover rates are one of the persistent problems in organizations. Meanwhile, Pires (2009) observes that the foremost critical issue for employees today in all industries is hiring and keeping qualified and capable employees. It is important to identify the causes for employee turnover to reduce it, so, 
according to many different scholars few of the factors that were identified are given next.

\section{Factors affecting Turnover Intention}

\section{Work Environment}

Shamsuzzoha \& Shumon (2010), argue that if the physical condition in the place of work is deficient of crucial amenities, it could discourage employees and promote employees' turnover. Work environment refers to the working conditions in which employees have to perform their duties. These conditions include work schedules, reporting times, nature of supervisors, nature of work, and work flexibility among others (Lee, Back and Chan 2015). Employees who prefer to work under less pressure may quit for an alternative, employment opportunities that promise less stress (Firth, David, Kathleen \& Claude, 2007). In an article investigating high turnover from international Journal of Business Management it is clarified that Kahn (1990), agreed with Robinson et al., (2004) that employees become engaged in their work if they receive socio -emotional and economic value for their work, when they do not receive what they expect, they tend to withdraw from their roles and disengage themselves.

\section{Reward and Recognition}

Shukla and Sinha (2013), observe that when an employee is engaged in a lowwage position with inadequate benefits, there is little or no motivation to continue if a comparable employer offers even a slightly higher rate of pay. Hissom (2009), asserts that the topmost factor that causes high labor turnover rate is salary structure since employees are rational and will often prefer employment that has comparable salary structure in place. Indian Journal of Science and Technology (2016) has found that "An organization should have proper salary systems in place to motivate the employees to work in the firm. To enhance the engagement level the employee must be provided with specific compensation and benefits".

\section{Relationship with Management}

The nature of the interrelationship between employees and management represents another factor that causes employees' turnover. If the interrelationship between employees and the management is poor, employees will not hesitate to quit for another employment at any available opportunity (Shukla\& Sinha, 2013). Moreover, Dale Carnegie \& Associates, (2012) says that Long-term engagement starts with effective communication between employer and employees as well as among coworkers, fostering a positive working environment. A feeling that management in general, or a particular manager and team leader is treating employees unjustly or is bullying his staff can lead to a high rate of employee turnover (Armstrong, 2004).

\section{Lack of Career Progression}

Europhia (2008) cited from Shukla and Sinha (2013) and reports that career development is a lot more significant than remuneration in Europe and America, but it is considered equivalent to remuneration in Asia. Increase in labor turnover could also be because of the lack of potential 
opportunity for promotions or elevations. According to ISR's (2004) study identified four issues as global factors in managing engagement; career development, leadership, empowerment, and image (which refers to the company's image to customers and the public).

\section{Employee Engagement}

According to Kahn (1990),
engagement is defined as the
attachment of the organization
members to their job roles.
Considerable research has been done on differentiating employee engagement from the other related constructs and making it measurable. For example, an employee is engaged if he can freely express himself physically, cognitively, and emotionally in his official role (Kahn. 1990; Purcell, 2006; Rich, Lepine, \& Crawford, 2010). Employee engagement can be defined in diverse ways. An engaged employee is one who produces results, does not change jobs frequently and more importantly is always the ambassador of the company (Arti et al., 2016). An employee could also be found to be experiencing three various levels of engagement. He could be engaged, not engaged, or disengaged. Engaged employees are those who work with passion towards the organization's goals. An employee who is not engaged is one who is seen to be participating but not with passion and energy towards the organization's common goal. Disengaged employees are those who are unhappy at their work and act out of their unhappiness (Arti et al., 2016). According to a study by (Bakker et al., 2012; Karatepe \& Olugbade, 2009; Ludwig \& Frazier,
2012; Markos \& Sridevi, 2010; Wheeler et al., 2012), engagement is affected by many factors involving both emotional and rational factors relating to work and the overall work experience. Robinson et al., (2004) defined employee engagement as "a positive attitude held by the employee towards the organization and its value. An organization's outcome is positively correlated with employee engagement, the lesser the number of engaged employees in a company, the less the efficiency of that company will be (Harter et al., 2013). Many researches and arguments were carried on employee engagement which states the distinction between job satisfaction and employee engagement. This was brought up by Fernandez (2007). This is because managers cannot retain people just by catering to employee satisfaction needs. It is further clarified as "Engagement is about passion and commitment - the willingness to invest oneself and expand one's discretionary effort to help the employer succeed. Within the employment arrangement, this is simple satisfaction or basic loyalty to the employer" (Saks, 2011; Yakın \& Erdil, 2012; Yeh, 2012). Kahn (1990), Harter et al., (2002) further defined employee engagement as "the individual's involvement and satisfaction as well as enthusiasm for work". Employee engagement is therefore the level of commitment and involvement an employee has towards his or her organization and its values. The construct of employee engagement is relatively new for HRM and appeared in the literature for nearly two decades (Robinson et al., 2005). Employee engagement is a positive force that motives and connects employees with their organization, 
either emotionally, cognitively or physically (Kahn, 1990; Wellins \& Concelman, 2005). More importantly, engaged employees are not only motivated, but they also understand the organization's business goals, the steps required to achieve those goals and how their contributions drive goals. Employee engagement is critical for, and an important element in, the success of organizations. Prior research has found that individuals seek more meaning in their dayto-day work than they do in their personal lives (Mishra et al., 2014; Ugwu et al., 2014). According to Saks (2006), the effective way for employees to repay their organization is through their level of engagement. Employees will choose whether to engage themselves in relation to the resources they get from their organization. This perception shows a reciprocal relationship between the supports that the organizations give to their employees and employee's willingness to make the most of their individual and team performance. The social exchange provides a theoretical foundation to justify the reasons why employees decide to engage on their work or stay with their organization.

During the course of many researchers conducted all over the world several factors have been found to affect the levels of engagement of an employee in an organization. A few of them are discussed under the following topic.

\section{Factors affecting Employee Engagement}

\section{Career Development}

Career development is one of the key factors that employees look for in an organization. Organizations with highly engaged employees provide opportunities to develop, learn new knowledge and skills, develop abilities, etc. According to Sandeep et al., (2008) career development is a global factor in employee engagement. It is stated by Neeta B. (2011) that employees tend to invest in companies that invest in them by planning for their career development. According to an article published by Christina et al, (2008), it is said that a friendly culture which promotes employee engagement is one which appreciates the diversity within its talent pool and prompts the employees to work towards the future.

\section{Leader-follower Relationship}

Employees display more engagement when they are aware that their work is valued and appreciated. They develop to be committed to the organization when they see themselves getting praised and identified by their immediate leaders, Employees need to be convinced that management listens, supports and recognizes their contributions in order to be more engaged (Pavlinac, 2009). Many employees still expect day-to-day informal recognition (Hofmans et al., 2012). A close analysis of these drivers indicates that conceptually leadership has a critical input in fostering employee engagement. Support for this argument comes from research by Wang and Walumbwa (2007) and Macey and Schneider (2008) that suggests leadership as being one of the single biggest factors affecting employee perceptions in the workplace and workforce engagement. Research has also indicated that the qualities of transformational leadership result in 
outcomes, such as lower intention to turnover and higher productivity, which are similar to those resulting from employee engagement (Macey \& Schneider, 2008; Walumbwa \& Hartnell, 2011). As per the social exchange theory (SET), relationships grow over time into trusting, loyal, and mutual pledges as long as the parties stand by certain "rules" of exchange. Exchanges between the supervisors and employees affect the level of engagement to a greater extent.

\section{Pay and Benefits}

People generally expect appreciation and recognition in return. This motivates and provides them with the emotional drive to get committed more. The absence of employee recognition and appreciation has been established by the U.S. Department of Labor as a key aspect in employees' decisions to quit their jobs in organizations (Holbeche, 1998). This can be only possible when the organization has a proper salary and benefit systems. To use salary as an effective engagement technique, the employer should attach it to jobs, performance, special or personal allowances, pensions, fringe benefits etc. In addition, extended employee care, reward and recognition have been shown to enhance employee skills, which will reflect positively on the overall performance (AbuKhalifeh \& Som, 2013).

\section{Communication}

Communication plays an important role in ensuring employee engagement (Pugh and Dietz, 2008; Wiley et al, 2010; Kahn 1992; MacLeod and Clarke, 2009) MacLeod and Clarke, 2009 emphasize employees require clear communication from superiors to relate their role with leadership vision. Long-term engagement starts with excellent communication between employer and employees as well as among co-workers. Clear communication between the higher management to lower level staff builds up a trustworthy, transparent, and loyal relationship. Internal communication is an organizational practice, which effectively conveys the organizational values to all employees and thus, obtains their support in reaching organizational goals. Thus, internal communication is crucial for ensuring employee engagement (Bindle and Parker, 2010; Papalexandris \& Galanaki, 2009; Bakker et al, 2011, as cited in Welch, 2011).

\section{Workplace Environment}

Work environment was found to be one of the significant factors that determine the engagement level of an employee. Studies by Miles (2001) and Harter et al. (2002), Holbeche and Springett (2003), May et al. (2004) and Rich et al. (2010) show that employee engagement is the result of various aspects of the workplace. Supportive environments allow members to experiment and to try new things and even fail without fear of the consequences (Kahn, 1990). Richman et al. (2008) argue that an organization's flexible work-life policies have a notable positive impact on employee engagement. Employees should feel the work is stress-free and interesting to maintain consistency in delivering quality work. 


\section{Employee Engagement vs. Labor Turnover}

With the literature from the previous findings given by different scholars it is evident that both employee engagement and labour turnover has a correlation. However, employee engagement is not an individual factor that merely contributes to the intention to turnover. It was clearly identified that Employee engagement acts as a mediating variable when the drivers of employee engagement and labour turnover are correlated. This is further clarified by the study done by Aon Hewitt Consulting on key drivers of employee engagement and willingness to leave the company are illustrated in the figure below. In this study, the researcher is focusing on finding the relationship between the drivers of both employee engagement and intention to turnover and thereby derive the relationship between the two.

\section{Theoretical Background}

According to Vroom (1964), the strength of tendency to act in a certain way depends on the strength of expectancy that the act will be followed by a given outcome and, on the value, or attractiveness of that outcome to the actor. According to the expectancy theory, employees are motivated to behave in a way which people believe will lead to desired outcomes. Generally, expectancy theory can be used to predict behavior in any situation in which a choice between two or more alternatives must be made. For example, it can be used to predict whether to leave or stay at a job and whether to try substantial or minimal effort at task (kreitner and Kinicki, 2001).Expectancy theory has been applied to a wide variety of studies such as student motivation in participating teaching evaluation process of their teachers, employees leaving firms and employee engagement (McShane, 2008).

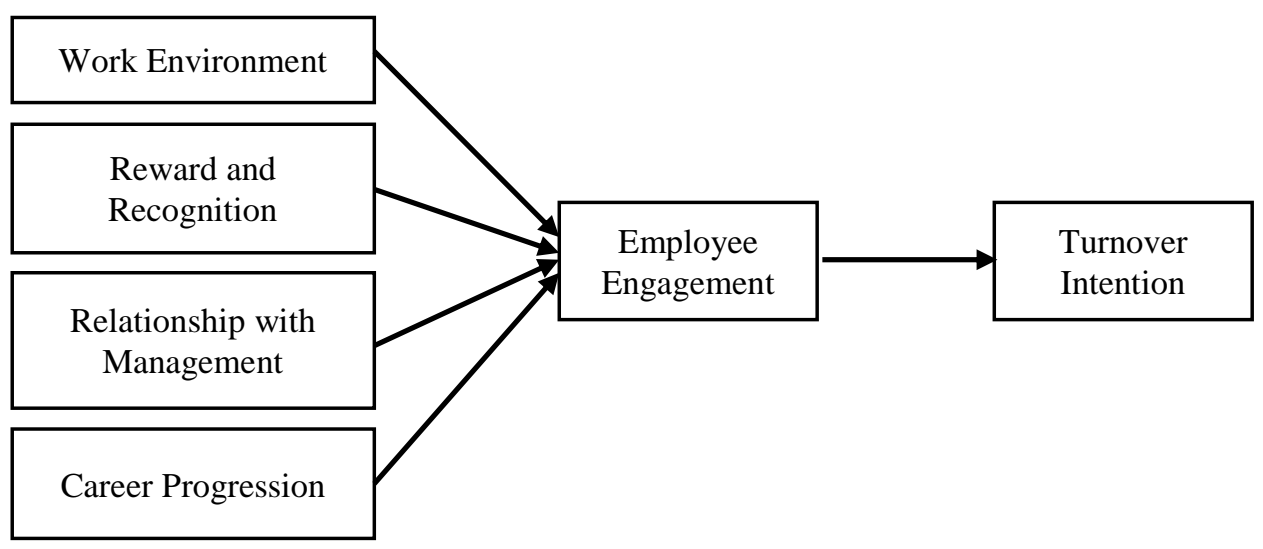

Figure 02: Conceptual Framework of the Study

Source: Author, 2019 


\section{Hypotheses}

A hypothesis is an indefinite statement constructed by researchers in search of conclusions for a particular problem statement. Majority of the researchers construct these interpretations using previous theory. In this study, the following hypotheses were interpreted using the previous theories and the preliminary investigations carried out by the researcher. These hypotheses can be tested using the analytical tool and accept or reject whichever is suitable or vice versa.

H1: There is a relationship between the work environment and employee engagement

H2: There is a relationship between rewards \& recognition and employee engagement

H3: There is a relationship between the relationship with management and employee engagement

H4: There is a relationship between career progression and employee engagement

H5: There is a relationship between the work environment and intention to turnover

H6: There is a relationship between rewards and recognition and intention to turnover

H7: There is a relationship between the relationship with management and the intention to turnover

H8: There is a relationship between career progression and intention to turnover
H9: There is a relationship between employee engagement and intention to turnover

\section{Research Design}

In this work, the researcher is approaching the deductive approach where hypotheses will be identified using the available facts and try to develop proven analysis using the data collected.

\section{Variables}

Independent Variables - The independent variables are the variables that the experimenter changes or controls and is assumed to have a direct effect on the dependent variable. So in this study there are four main independent variables identified. Work Environment, Reward and recognition, Relationship with Management, Career progression.

Dependent Variable - The dependent variable is a key area that has been tested (affected) by the abovementioned factors. This will be tested and measured in the research experiment. At this work, intention to turnover will be the dependent variable.

Mediating Variable - Apart from the dependent and the independent variables, it was identified that another mediating factor which is influenced by independent variables which affects the dependent variable. This is known as the mediator where in this study Employee engagement will be considered to be the mediating variable, The researcher is intending to identify the relationship between the independent variables and the 
mediating variable (Employee engagement) and thereby derive the relationship between the mediating variable (Employee engagement) with the dependent variable (intention to turnover).

\section{Sample}

Population - In this study, the target population was the tutor grade staff (Non- executive) which comprises 200 individuals.

Sample - A total of 132 tutors were included in the questionnaire survey in TSG, out of which a sample of 100 valid responses was received after neglecting incomplete and invalid responses. Participants were asked to fill the questionnaires during their regular working hours. Before distributing the questionnaire, all participants were assured that their participation was voluntary, and anonymity was guaranteed.

Sampling method - In selecting a sample to study it should represent the full set of cases in a way that is meaningful and which we can justify. (Becker 1998). The amount of data received is quite less when compared to a census, however, this may give more detailed and accurate information. Different techniques can be used to sample out a population depending on the research methodology and the hypotheses that need to be tested. In this study, the technique used is a random sampling technique where a collection of individuals is randomly selected to participate in the survey depending on their willingness.

As per the table of sampling size of Uma Sekaran (2006), the sample size for the population of 200 should be 132.

The arrangement of the sample was taken as:

- The population of nonexecutives - 200

- Random sample formulation 132

- Valid responses - 100

\section{Data Collection}

The primary data collection was done through a questionnaire. Biographical questions were included in the survey to analyze and determine the results based on how factors like age, gender, years of experience, education level, etc. impact on the intention to turnover in alignment with employee engagement. These questions were based on the independent variables to analyze the effectiveness of each within the organization and employee's agreement towards each of those on a scale of $0-4$. This helps to derive data numerically. The type of scale used in this research is the Likert scale where the values are ranging from $0-4$.

\section{Data Analysis}

In this research, the main method of data analysis utilized is quantitative methods.

The conceptual framework has been constructed using the past literature. Research method, design was based on the onion model while the scales, question designs and operationalization of the framework were also briefed and linked with the questionnaire sent for the sample. Also, hypothesis was developed based on the 
dependent, independent, and mediating variables identified using literature.

The reliability tests done for each variable and all the independent, mediating, and dependent variables meet the Cronbach's alpha test with a value greater than 0.7 , hence the questionnaire was ideal to distribute and conduct the research.

\section{Results}

\section{Correlation Analysis}

Table 01: Correlation Statistics

\begin{tabular}{|c|c|c|c|}
\hline \multicolumn{2}{|l|}{ Variables } & $\begin{array}{c}\text { Pearson } \\
\text { Correlation }\end{array}$ & $\begin{array}{c}\text { Type of } \\
\text { relationship }\end{array}$ \\
\hline \multirow{2}{*}{$\begin{array}{l}\text { Workplace } \\
\text { environment }\end{array}$} & $\begin{array}{l}\text { Employee } \\
\text { engagement }\end{array}$ & 0.646 & Strong positive \\
\hline & Intention to turnover & -.942 & Strong negative \\
\hline \multirow{2}{*}{$\begin{array}{l}\text { Reward \& } \\
\text { Recognition }\end{array}$} & $\begin{array}{l}\text { Employee } \\
\text { engagement }\end{array}$ & 0.587 & Strong positive \\
\hline & Intention to turnover & -.920 & Strong negative \\
\hline \multirow{2}{*}{$\begin{array}{l}\text { Relationship with } \\
\text { management }\end{array}$} & $\begin{array}{l}\text { Employee } \\
\text { engagement }\end{array}$ & 0.652 & Strong positive \\
\hline & Intention to turnover & -.844 & Strong negative \\
\hline \multirow[t]{2}{*}{ Career progression } & $\begin{array}{l}\text { Employee } \\
\text { engagement }\end{array}$ & 0.935 & Strong positive \\
\hline & Intention to turnover & -.659 & Strong negative \\
\hline $\begin{array}{l}\text { Employee } \\
\text { engagement }\end{array}$ & Intention to turnover & -.662 & Strong negative \\
\hline
\end{tabular}

Source: Author, 2019

When comparing the workplace components and employee engagement, the Pearson correlation value is 0.646 . This is directed toward a positive correlation, which explains that it is a strong positive correlation. The coefficient determination value is $\left(\mathrm{R}^{2}\right.$ linear) is 0.418 . The significant value is 0.000 which means the probability value ( $\mathrm{p}$-value) is less than 0.05 . Therefore, $(\mathrm{r}(100)=.646, \mathrm{p}=$ $.000)$.

When looking at the correlation between workplace components and intention to turnover it gives a different aspect compared to the previous. The Pearson correlation value (r) equals to -.942 which indicates that it is directed towards a negative correlation. This is also a strong negative correlation. The coefficient determination value $\left(\mathrm{R}^{2}\right.$ Linear) is 0.887 , and the value of significance is .000 . Hence, the probability value (p-value) is lower than 0.05. $(r(100)=-.942, p=.000)$

Rewards, recognition with employee engagement has a strong positive correlation with the Pearson correlation value (r) equals to 0.587 . The coefficient determination value $\left(\mathrm{R}^{2}\right.$ 
linear) is 0.344 . The significance value is 0.000 which means the probability value (p-value) is less than 0.05 . $(\mathrm{r}(100)=0.587, \mathrm{p}=.000)$

Rewards and recognition components with turnover intention has a strong negative correlation and the Pearson's correlation value being -0.92 . The coefficient determination value $\left(\mathrm{R}^{2}\right.$ linear) is 0.846 . The significance value is 0.000 which means the probability value (p-value) is less than 0.05 . $(\mathrm{r}(100)=0.228, \quad \mathrm{p}=.000)$. This interprets that when rewards and recognition get higher, the intention to turnover gets low.

The Pearson correlation value ( $r$ ) for the relationship of management with employee engagement equals to 0.652 . This is directed towards a strong positive correlation. The coefficient determination value $\left(\mathrm{R}^{2}\right.$ linear $)$ is 0.426 . The significance value is 0.000 which means the probability value ( $\mathrm{p}$ value) is less than 0.05; $(\mathrm{r}(100)=$ $0.652, \mathrm{p}=.000$ ).

\section{Regression Analysis}

In the following table regression analysis done for each variable is given and the appendix $b$ contains the illustrations of each individually.

Table 02: Regression Statistics

\begin{tabular}{|l|c|c|l|l|l|}
\hline Variable & R2 & $\begin{array}{c}\text { P } \\
\text { value }\end{array}$ & $\begin{array}{l}\text { Simple regression } \\
\text { equation }\end{array}$ & Predicted TOI & Relationship \\
\hline $\begin{array}{l}\text { Workplace } \\
\text { environment }\end{array}$ & 0.892 & .000 & $\begin{array}{l}(\mathrm{F}(2,97)=399.522, \\
\mathrm{p}<.05\end{array}$ & $\begin{array}{l}6.443-1.071- \\
.104\end{array}$ & $\begin{array}{l}\text { Strong } \\
\text { positive }\end{array}$ \\
\hline $\begin{array}{l}\text { Reward \& } \\
\text { recognition }\end{array}$ & 0.869 & .000 & $\begin{array}{l}(\mathrm{F}(2,97)=320.773, \\
\mathrm{p}<.05\end{array}$ & $\begin{array}{l}6.351-.988- \\
.211\end{array}$ & $\begin{array}{l}\text { Strong } \\
\text { positive }\end{array}$ \\
\hline $\begin{array}{l}\text { Relationship } \\
\text { with } \\
\text { management }\end{array}$ & 0.735 & .000 & $\begin{array}{l}(\mathrm{F}(2,97)=134.346, \\
\mathrm{p}<.05\end{array}$ & $\begin{array}{l}6.744-1.108- \\
.218\end{array}$ & $\begin{array}{l}\text { Strong } \\
\text { positive }\end{array}$ \\
\hline $\begin{array}{l}\text { Career } \\
\text { progression }\end{array}$ & 0.452 & .000 & $\begin{array}{l}(\mathrm{F}(2,97)=39.938, \\
\mathrm{p}<.05\end{array}$ & $\begin{array}{l}4.832-.323- \\
.410\end{array}$ & $\begin{array}{l}\text { Strong } \\
\text { positive }\end{array}$ \\
\hline $\begin{array}{l}\text { Employee } \\
\text { engagement }\end{array}$ & 0.439 & .000 & $\begin{array}{l}(\mathrm{F}(1,98)=76.647, \\
\mathrm{p}<.05\end{array}$ & $4.915-.745$ & $\begin{array}{l}\text { Strong } \\
\text { positive }\end{array}$ \\
\hline
\end{tabular}

Source: Author, 2019

Table 03: Hypothesis Testing Results

\begin{tabular}{|c|c|l|c|c|}
\hline \multicolumn{2}{|c|}{ Hypotheses Tested } & P value & Decision \\
\hline H1 & Ho1 & $\begin{array}{l}\text { There is no relationship between the work } \\
\text { environment and employee engagement }\end{array}$ & .000 & Reject \\
\hline
\end{tabular}




\begin{tabular}{|c|c|c|c|c|}
\hline \multicolumn{3}{|r|}{ Hypotheses Tested } & \multirow{2}{*}{$\begin{array}{c}\text { P value } \\
.000\end{array}$} & \multirow{2}{*}{$\begin{array}{l}\text { Decision } \\
\text { Accept }\end{array}$} \\
\hline & Ha1 & $\begin{array}{l}\text { There is a relationship between the work } \\
\text { environment and employee engagement }\end{array}$ & & \\
\hline \multirow{2}{*}{$\mathrm{H} 2$} & Но2 & $\begin{array}{l}\text { There is no relationship between rewards and } \\
\text { recognition and employee engagement }\end{array}$ & .000 & Reject \\
\hline & $\mathrm{Ha} 2$ & $\begin{array}{l}\text { There is a relationship between rewards and } \\
\text { recognition and employee engagement }\end{array}$ & .000 & Accept \\
\hline \multirow{2}{*}{ H3 } & Ho3 & $\begin{array}{l}\text { There is no relationship between the relationship } \\
\text { with management and employee engagement }\end{array}$ & .000 & Reject \\
\hline & $\mathrm{Ha} 3$ & $\begin{array}{l}\text { There is a relationship between the relationship } \\
\text { with management and employee engagement }\end{array}$ & .000 & Accept \\
\hline \multirow{2}{*}{$\mathrm{H} 4$} & Ho4 & $\begin{array}{l}\text { There is no relationship between career progression } \\
\text { and employee engagement }\end{array}$ & .000 & Reject \\
\hline & $\mathrm{Ha} 4$ & $\begin{array}{l}\text { There is a relationship between career progression } \\
\text { and employee engagement }\end{array}$ & .000 & Accept \\
\hline \multirow{2}{*}{ H5 } & Ho5 & $\begin{array}{l}\text { There is no relationship between the work } \\
\text { environment and intention to turnover }\end{array}$ & .000 & Reject \\
\hline & Ha5 & $\begin{array}{l}\text { There is a relationship between the work } \\
\text { environment and intention to turnover }\end{array}$ & .000 & Accept \\
\hline \multirow{2}{*}{ H6 } & Ho6 & $\begin{array}{l}\text { There is no relationship between rewards and } \\
\text { recognition and intention to turnover }\end{array}$ & .000 & Reject \\
\hline & Ha6 & $\begin{array}{l}\text { There is a relationship between rewards and } \\
\text { recognition and intention to turnover }\end{array}$ & .000 & Accept \\
\hline \multirow{2}{*}{ H7 } & Ho7 & $\begin{array}{l}\text { There is no relationship between the relationship } \\
\text { with management and the intention to turnover }\end{array}$ & .000 & Reject \\
\hline & $\mathrm{Ha} 7$ & $\begin{array}{l}\text { There is a relationship between the relationship } \\
\text { with management and the intention to turnover }\end{array}$ & .000 & Accept \\
\hline $\mathrm{H} 8$ & Ho8 & $\begin{array}{l}\text { There is no relationship between career progression } \\
\text { and intention to turnover }\end{array}$ & .000 & Reject \\
\hline
\end{tabular}




\begin{tabular}{|c|c|l|c|c|}
\hline \multicolumn{2}{|c|}{ Hypotheses Tested } & P value & Decision \\
\hline H9 & Ho9 & $\begin{array}{l}\text { There is a relationship between career progression } \\
\text { engagement and intention to turnover }\end{array}$ & .000 & Accept \\
\hline & Ha9 & $\begin{array}{l}\text { There is a relationship between employee } \\
\text { engagement and intention to turnover }\end{array}$ & .000 & Reject \\
\hline
\end{tabular}

Source: Author, 2019

\section{Conclusion}

An empirical research has been carried-out to identify and analyze the "Impact of employee engagement on the intention to turnover: with special reference to Third Space Global PVT Ltd. The main objective of this research was to identify the factors affecting employee turnover and study the relationship between employee engagement, and intention to turnover. Finally, recommendations and justifications have given in terms of short-term and long-term perspective while further areas for research concludes the whole research.

In order to achieve the general aim of the study, the researched analyses few specific objectives as mentioned below:

- $\quad$ Identify key factors affecting intention to turnover within the tutor grade employee in the company

- $\quad$ Explore the level of employee engagement existing in the company

- $\quad$ Analyze the relationship between employee engagement and intention of turnover
- Study the impact of strategies of techniques that influence the rate of attrition

In the satisfaction of these questions, the researcher initiated the process with studying the literature based on intention to turnover and identified key factors related. Also, the researcher conducted a preliminary research by having conversations with HR, Line managers and randomly picked nonexecutive employees to identify the conditions that affect intention to turnover while collecting secondary data on the turnover rate and exit interview from HR related documents. Though, these documents were not expressly received to analyze, the researcher was able to gain an understanding on the key factors influencing the rate of attrition while having discussions with the HR.

After exploring the current level of engagement within the company, the researcher followed with sending questionnaire to analyze the relationships between the key factors identified using previous theories and derived hypothesis accordingly. As evident in Chapter 4, the analysis of 
those key factors was conducted, and it was proved that the relationships of those variables were significant and strongly related. As a result, all null hypothesis was rejected.

As per the findings it was identified that the company did utilize few of the techniques that motivated the employees to retain. However, there were also some loopholes that can be improved.

\section{Recommendations}

\section{Improve the compensation and reward system based on the level of experience}

As per the findings it was identified that employees who are with more than 2 years of working experience still get paid the same as employees who are with 1-2 years of working experience. Also, the education level of each individual has no much of an impact in relation to their pay. This has brought a negative impression towards retaining in the job. The company can focus on allocating reward or incentive systems based on the years of working experience and the education level rather following an inflation rate system.

\section{Provide more learning opportunities within the job scope}

It was said that the employees are tired of working on routine-based job which is deliver six sessions daily. It is quite difficult to change the production job role, however, the company can focus on implementing professional or personal development skill trainings, once a month and also allow the employees to explore the job scope of executive level employees which would give them a sense of value.

\section{Improve on the current employee engagement practices}

The company can suggest employees to be involved with conducting different events, games, recreational activities to build their engagement and have a good relationship with the management. The current practices are limited only for outdoor activities which requires a long-term planning and high budget on execution. The company can focus online based activities as per the current situation of pandemic, majority of the employees are working remotely.

\section{Adopt informal/internal communication systems to build relationships among employees as well as the management}

Utilizing different communication channels like slack, office vibe and random friendly team huddles would help to build the interaction with the employees and thereby improve the relationship between employees and management. Some of the nonexecutive staff were feeling laid back to voice out their opinions freely. This can be mitigated by adopting the open culture and build the trust within the employees. 
Naufer \& Kumar, KJHRM 2020, 15(01)

\section{References}

Abdien, M. (2019). Impact of communication satisfaction and work-life balance on employee turnover intention. Journal of Tourism Theory and Research, 228238. doi: $10.24288 / \mathrm{jttr} .526678$

Abraham, R. (1999). The Impact of Emotional Dissonance on Organizational Commitment and Intention to Turnover. The Journal of Psychology, 133(4), 441-455. doi: 10.1080/00223989909599754

Agarwal, R. (2017). Employee Engagement \& Retention: A Review of Literature. International Journal of BRIC Business Research, 6(1), 01-19. doi: 10.14810/ijbbr.2017.6101

Armstrong, M., \& Taylor, S. (2017). Armstrong's Handbook of Human Resource Management Practice (14th ed., 389-399). New York, USA: Kogan Page.

Arora, R. (2016). Role of Performance Improvement and Instructional Design in Strategic Human Resource Management. Journal of Strategic Human Resource Management, 5(1). doi: 10.21863/jshrm/2016.5.1.022

Ashton, C., \& Morton, L. (2005). Managing talent for competitive advantage: Taking a systemic approach to talent management. Strategic HR Review, 4(5), 28-31. doi: $10.1108 / 14754390580000819$

B., A. (2018). Research on the Relationship between Human Resource Management Practices and Employee Retention in Chinese Overseas Enterprise Evidence from Huawei in Senegal. Journal of International Business Research and Marketing, 3(3), 7-22. doi: 10.18775/jibrm.1849-8558.2015.33.3001

Budhwar, P., Varma, A., Malhotra, N., \& Mukherjee, A. (2009). Insights into the Indian call centre industry: can internal marketing help tackle high employee turnover. Journal of Services Marketing, 23(5), 351-362. doi:

10.1108/08876040910973459

Chandani, A., Mehta, M., Mall, A., \& Khokhar, V. (2016). Employee Engagement: A Review Paper on Factors Affecting Employee Engagement. Indian Journal of Science and Technology, 9(15). doi: 10.17485/ijst/2016/v9i15/92145

Crosby, D. (2014). Improving Employee Retention in the Public Sector by Increasing Employee Engagement. SSRN Electronic Journal. doi: $10.2139 /$ ssrn.2555709 
Firth, L., Mellor, D., Moore, K., \& Loquet, C. (2004). How can managers reduce employee intention to quit? Journal of Managerial Psychology, 19(2), 170187. doi: 10.1108/02683940410526127

Harisa Putri, W., \& Ronald Setianan, A. (2019). Job enrichment, organizational commitment, and intention to quit: the mediating role of employee engagement. Problems and Perspectives in Management, 17(2), 518-526. doi: $10.21511 / \mathrm{ppm} .17(2) .2019 .40$

Ibrar, M., \& Khan, O. (2015). The Impact of Reward on Employee Performance (A Case Study of Malakand Private School). International Letters of Social and Humanistic Sciences, 52, 95-103.

Jose, J., \& Dr. N. Panchanatham, D. (2011). Influence of Job Satisfaction and Organizational Commitment on Job Involvement towards Organizational Effectiveness. Indian Journal of Applied Research, 4(1), 280-282. doi: $10.15373 / 2249555 \mathrm{x} / \mathrm{jan} 2014 / 81$

Kahn, W. A., \& Fellows, S. (2013). Employee Engagement and Meaningful Work.

S. Byrne, \& M. F. Steger (Eds.), Purpose and meaning in the workplace (p. 105-126). American Psychological Association. https://doi.org/10.1037/14183-006

Lambert, E., Lynne Hogan, N., \& Barton, S. (2001). The impact of job satisfaction on turnover intent: a test of a structural measurement model using a national sample of workers. The Social Science Journal, 38(2), 233-250. doi: 10.1016/s0362-3319(01)00110-0

Li, Y., \& Sawhney, R. (2019). Empirical Analysis of Factors Impacting Turnover Intention among Manufacturing Workers. International Journal of Business and Management, 14(4). doi: 10.5539/ijbm.v14n4p1

Lockwood, N. R. (2007). Leveraging Employee Engagements for Competitive Advantage: HRs Strategic Role. HR Magazine, 52(3), 01-11.

Meirina, I., Ferdian, F., Pasaribu, P., \& Suyuthie, H. (2018). The Influence of Work Environment towards Turnover Intention of Employee of 4 Star Hotels in Padang City. Journal of Business on Hospitality and Tourism, 4(2), 97. doi: 10.22334/jbhost.v4i2.120

Morrell, K., Loan-Clarke, J., \& Wilkinson, A. (2004). Organizational change and employee turnover. Personnel Review, 33(2), 161-173. doi: $10.1108 / 00483480410518022$

Moussa, M. (2013). Investigating the High Turnover of Saudi Nationals versus NonNationals in Private Sector Companies Using Selected Antecedents and Consequences of Employee Engagement. International Journal of Business and Management, 8(18). doi: 10.5539/ijbm.v8n18p41 
Nursanti, T., \& Then, T. (2019). The Influence of Job Resources towards Employee Engagement and Its Impact on Turnover Intention of the Employees of PT Bank DKI. doi: 10.35384/jime.v11i1.124

Rajapaksha, U. (2015). A Study on the Impact of Recruitment Methods on Employee Turnover (Reference to Banking Sector in Sri Lanka). SSRN Electronic Journal. doi: 10.2139/ssrn.2699788

Saks, A., \& Gruman, J. (2014). What Do We Really Know About Employee Engagement? Human Resource Development Quarterly, 25(2), 155-182. doi: 10.1002/hrdq.21187

Sandeep, Chris R, Emma S, Katie T, Mark G. Employee Engagement: Kingston Business School Working Paper. 2008; 19.

Saunders, M., Lewis, P., \& Thornhill, A. (2009). Research Methods for Business Students (5th ed.).

Sekaran. (2006). Research methods for business - a skill building approach 5e set. [Place of publication not identified]: John Wiley \& Sons Inc.

Siddiqui, A., \& Jamil, R. (2015). Antecedents of Employees Turnover Intentions: Evidence from Private Educational Institutions. American Journal of Economics and Business Administration, 7(4), 160-165. doi: 10.3844/ajebasp.2015.160.165

Soane, E., Truss, C., Alfes, K., Shantz, A., Rees, C., \& Gatenby, M. (2012). Development and application of a new measure of employee engagement: the ISA Engagement Scale. Human Resource Development International, 15(5), 529-547. doi: 10.1080/13678868.2012.726542 